\title{
THE UNUSUAL CASE OF THE DISCOUNT OFFERS FOR TAKING THE CONTROL: EVIDENCE FROM ROMANIA
}

\section{Victor Dragotă, Radu Ciobanu*}

\begin{abstract}
Most of the studies regarding control premium are focussed on the case in which it is positive. We considered the case when it is negative, investigating the determinants of the discount for control, having as study case the Romanian listed companies.

Comparative to the general case of control premium, discounts for control are also determined by some other specific factors, like the number of non-trading days and the cash ratio. Some determinant factors of control premium have an opposite influence when this is negative: the percentage of shares purchased in the transaction, the ownership concentration, the fact the buyer or the seller is domestic, and the existence of a major shareholder owning more than $50 \%$ of shares. Consequently, some factors usually used in explaining the control premium cannot be suitably used for the case of the discount for control. Moreover, the negative impact of the undiversified portfolio is validated.
\end{abstract}

Keywords: control premium, discount offer, discount for control, mergers and acquisitions, agency problems, Romania

JEL Classification: G34

\section{Introduction}

Issues like takeovers and control premium (value of control) are discussed in a large number of papers. Mergers and acquisitions are usually explained in the business valuation literature as a manner to increase the value of the invested capital in the companies, in close connection to synergistic effects, due to different beneficial effects on revenues, costs, tax reductions or cost of capital (Ross et al., 2010). By assuming his or her role in monitoring the managers, taking a controlling position, a larger shareholder can determine

* Victor Dragotă, Bucharest University of Economic Studies, Faculty of Finance, Insurance, Banking and Stock Exchange, Department of Finance and CEFIMO, Bucharest, Romania (victor.dragota@fin.ase.ro);

Radu Ciobanu, Bucharest University of Economic Studies, Faculty of Finance, Insurance, Banking and Stock Exchange, Department of Finance and CEFIMO, Bucharest, Romania (radu.ciobanu@fin.ase.ro).

This work was partially financed by CEFIMO. Radu Ciobanu had financial contribution from the European Social Fund through Sectoral Operational Programme Human Resources Development 2007-2013, Project No. POSDRU/159/1.5/S/134197 "Performance and Excellence in Doctoral and Postdoctoral Research in Romanian Economics Science Domain". Authors would like to express their gratitude to the Bucharest Stock Exchange (BSE) representatives, and especially to Mrs. Daniela Şerban, Financial Controller of Bucharest Stock Exchange. The results and the conclusions of the paper are entirely our responsibility, and BSE cannot be held liable for any of the opinions stated in our research paper. We also wish to thank to the participants of the EMU-SSEM Euro Conference in Famagusta (2013) and of the CEFIMO Seminar (2013) in Bucharest, K. Abadir, I.M. Dragotă, C. Lipară, A. Semenescu, E. Ţilică and two anonymous referees, for their useful suggestions. The remaining errors are ours. 
an increase in the value of invested capital (Shleifer and Vishny, 1986). Becoming a larger shareholder can be a way to protect personal wealth, especially in the post-communist economies, where the shareholders rights are not always protected (Shleifer and Vishny, 1997). Moreover, in some cases, from the private benefits of the controlling shareholders can benefit the minority shareholders, too. For instance, the interest of the controlling shareholder to gain a higher social position (e.g. a political career) will make his or her behaviour consistent with the interests of the minority shareholders (Holderness, 2003). In some cases, especially in emerging economies, conglomerates can protect somehow the companies in their turbulent environment, characterized by corruption, poor institutions, or imperfect capital markets, so an interest to acquire a controlling package of shares can be justified (Lefort and Walker, 2007). For all these reasons, a (positive) control premium (an offer price higher than the market price before the announcement) is logically supposed in most cases.

The control premium can also be explained in the context of agency problems between the controlling and the minority shareholders (Maury and Pajuste, 2005). The controlling shareholders can be interested to use their position to increase their wealth, even expropriating the minority shareholders (Shleifer and Vishny, 1997). In this case, too, the interest for taking control implies a (positive) control premium.

Whether the control premium is analysed in the context of synergistic effects or of the one of agency problems, it can be estimated as the sum of all the advantages produced for the shareholder by his or her controlling position. In this perspective, the general assumption is that the control premium should be positive. An extensive part of the financial literature deals with the issue of the control premium and its determinants (Nenova, 2003; Dyck and Zingales, 2004, among others). Even the term 'premium' suggests a higher value from the controlling position comparative to a minority one. Moreover, the generally accepted term in literature is 'control premium'.

In this context, the analysis of the discount offers and of the costs of control seems to be somehow neglected. However, Barclay and Holderness (1989) notice that the controlling position determines an undiversified portfolio, thus inducing a cost of control. Another explanation for the existence of discount transaction can be that ownership is in a permanent restructuring in developing economies, so private investors simply give up the shares at a lower market price and seek for another opportunity that can bring them a higher profitability (De Paula et al, 2002). Still, these cases seem to be exceptions. Interestingly, in some papers, even the term 'negative control premium' is preferred to the one of 'discount for control'1 (e.g. Barclay and Holderness, 1989), supporting the general opinion that the control benefits prevail over the control costs. In fact, Barclay and Holderness (1989) explain that the negative control premium occurs when private costs of control exceed the private benefits, and also why the negative control premium is hard to be understood: if the controlling shareholders would be disadvantaged by their control position, they would sell their shares in smaller blocks until they benefit from the higher price, characteristic for a non-controlling position.

Even so, discounts for control are still reported. Barclay and Holderness (1989) account $20 \%$ of their sample on U.S. market as transactions with negative control premiums. Discounts for control, estimated as negative voting premiums, are also reported by Ødegaard

1 Conceptually, in the business valuation literature, a negative premium is called discount. 
(2007) for Norwegian companies. For Romanian capital market, negative control premiums are recorded in $10.40 \%$ of transactions of the total database of Dragotă et al. (2013).

As a post-communist East European country, which has acceded to the European Union, Romania can be an interesting study case. The Romanian listed companies can have interesting growth opportunities, but also agency problems have been revealed in different contexts (see Pop, 2006, for mergers and acquisitions market). Both explanations suggest the normality of the (positive) control premium. However, the tender offers with a discount for control are present and persistent (see Table 1). In the period 2000-2014 (August), almost $12 \%$ of all tender offers aiming at control are discounted tender offers. ${ }^{2}$ The discounted tender offers are a stable presence in the market of control. Moreover, it is not explainable as in Fidrmuc (2007) by the existence of state as major shareholder, selling shares at discount in the privatization process $^{3}$.

Table 1 | Number of Discounted Tender Offers in Romania per Year in the Period 2000-2014

\begin{tabular}{|l|c|c|c|c|c|}
\hline $\mathbf{( 1 )}$ & $\mathbf{( 2 )}$ & $\mathbf{( 3 )}$ & $\mathbf{( 4 )}$ & $\mathbf{( 5 )}$ \\
\hline Year & $\begin{array}{c}\text { Tender Offers } \\
\text { Aiming at Control } \\
\text { and Finished with } \\
\text { Gaining it }\end{array}$ & $\begin{array}{c}\text { Tender Offers } \\
\text { Aiming at Control } \\
\text { but Finished } \\
\text { without Gaining it }\end{array}$ & $\begin{array}{c}\text { Total Tender } \\
\text { Offers Aiming } \\
\text { at Gaining } \\
\text { it (2) + (3) }\end{array}$ & $\begin{array}{c}\text { Discounted } \\
\text { Tender } \\
\text { Offers }\end{array}$ & $\begin{array}{c}\text { Percentage } \\
\text { of Discounted } \\
\text { Tender Offers }\end{array}$ \\
\hline $\mathbf{2 0 0 0}$ & 54 & 37 & 91 & 9 & 9.89 \\
\hline $\mathbf{2 0 0 1}$ & 63 & 31 & 94 & 14 & 14.89 \\
\hline $\mathbf{2 0 0 2}$ & 29 & 18 & 47 & 2 & 4.26 \\
\hline $\mathbf{2 0 0 3}$ & 30 & 21 & 51 & 4 & 5.88 \\
\hline $\mathbf{2 0 0 4}$ & 25 & 16 & 41 & 5 & 12.20 \\
\hline $\mathbf{2 0 0 5}$ & 11 & 10 & 21 & 4 & 19.05 \\
\hline $\mathbf{2 0 0 6}$ & 5 & 5 & 10 & 0 & 0.00 \\
\hline $\mathbf{2 0 0 7}$ & 5 & 5 & 10 & 2 & 20.00 \\
\hline $\mathbf{2 0 0 8}$ & 1 & 5 & 6 & 3 & 50.00 \\
\hline $\mathbf{2 0 0 9}$ & 1 & 1 & 2 & 1 & 50.00 \\
\hline $\mathbf{2 0 1 0}$ & 1 & 4 & 5 & 1 & 20.00 \\
\hline $\mathbf{2 0 1 1}$ & 2 & 0 & 2 & 0 & 0.00 \\
\hline $\mathbf{2 0 1 2}$ & 2 & 3 & 5 & 0 & 0.00 \\
\hline $\mathbf{2 0 1 3}$ & 1 & 4 & 5 & 0 & 0.00 \\
\hline $\mathbf{2 0 1 4}$ & 4 & 234 & 46 & 11.62 \\
\hline Total & 23 & 5.67 \\
\hline
\end{tabular}

Source: Own calculation, based on data provided by Bucharest Stock Exchange.

2 From the total number of successful tender offers (finished with the gain of control, 234 in our database), 28 (respectively 11.94\%) were discounted tender offers.

3 In our database, the Romanian state was shareholder in 10 companies: only in 2 of them, its stake was higher than $50 \%$ before the transaction (63\%, respectively $51 \%$ ), in 4 it was between $10 \%$ and $50 \%$, and in 4 it was lower than $5 \%$. 
The issues of the discount offers and of the discount for control and its determinants are sparsely discussed in the financial literature, so this study can be considered as covering the gap between the large number of papers dealing with the general case of control premium ${ }^{4}$ and the relatively few papers that analyse specifically the discount for control. Analysing the discount for control, we have found that it is characterized by some specific factors, different from those characteristics for the control premium. Even more important, the coefficient sign of some determinant factors of the control premium in the general case change if the control premium is negative. Consequently, some factors usually used in explaining the control premium cannot be suitably used for the case of the discount for control. Moreover, the hypothesis of the negative impact of the costs related to the undiversified portfolio is validated.

We also observed that, at least for Romanian listed companies, the square of the percentage of shares purchased in the transaction $\left(\mathrm{PSP}^{2}\right)$ better explains both control premium and discount for taking the control comparative to PSP. This observation can be useful in the construction of different explanatory models for the control premium estimation.

Further, the study is structured as follows. In Section 2 the main findings of other studies in the field as well as the hypotheses tested are briefly presented. The methodology and the data are presented in Section 3. Section 4 outlines the main results and also compare them with the ones obtained in Dragotă et al. (2013) for the general case of control premium, for the Romanian listed companies. The final section contains the conclusions and some directions for the future research.

\section{Literature Review and Tested Hypotheses}

An extensive financial literature is dealing with the issue of control premium, in general connected to the advantages given by control. Many studies investigate the size of the control premium and its determinants (Nenova, 2003; Dyck and Zingales, 2004, among a long list of papers). Different studies highlighted the differences from one country to another (Nenova, 2003) or from one industry to another (Andrade et al., 2001).The difference between the tender offer price and the price before the announcement can be explained through synergistic effects, agency problems, bargaining powers of the participants to transaction, lack of liquidity for the shares of the acquired company, but also through a lower level for the market efficiency (Dragotă et al., 2013).

We cannot find many studies that examined the discount for control. The presence of discounts for control (the negative control premium) is stated in some studies, but this is not their focus (Barclay and Holderness, 1989; Ødegaard, 2007; Kruse and Suzuki, 2013). It seems that the transactions in which the offer price is below the market price before the offer are considered mainly as exceptions, or, maybe, abnormal cases.

For the case of Romanian listed companies, Dragotă et al. (2013) validated nine hypotheses regarding the control premium, derived from the mainstream of the financial literature (see, also, Table 6). We explore if some of the determining factors of the control premium are different than their counterparts in the case of the discount for control. The first tested hypothesis of this study is:

$4 \quad$ In the text, we refer to the general case as the case in which there are analysed both positive and negative control premiums, as in Dragotă et al. (2013) for the Romanian listed companies. 
Hypothesis 1: The size of the discount for control is determined by some specific factors, different from those characteristics for the general case of control premium.

If validated, this hypothesis has one important practical implication: the factors which are usually used in explaining the control premium are not appropriate for the case of the discount for control. In the same context, it can be interesting to find the factors that have a similar impact both on the control premium and on the discount for control.

The size of the discount can be considered as a quantification of a sanction for having the control, with an opposite sense comparative to the case of the control premium. Specific for the discounts for control, from the seller's viewpoint, we have tested if the hypothesis of non-diversification of the portfolio, stated by Barclay and Holderness (1989), is validated for the case of Romanian listed companies. The position of the buyer is easily understandable from a rational point of view: he or she is accepting to take the control, paying a lower price comparative to the market price.

However, the existence of a controlling position does not provide answers to the question why the seller does not trade in smaller packages of shares, at a potential higher price. One reasonable explanation can be the seller's acute lack of liquidity, forcing him or her to accept a lower price than the price available on the market for shares in smaller packages. This hypothesis cannot be accepted easily if the offer is launched by the buyer. Another explanation can be given by a different bargaining power of the two agents ${ }^{5}$.

Control premium and discount for control can be interpreted in two ways. On the one hand, a discount for control can be understood as a negative control premium. On the other hand, a discount for control can be understood as a magnitude of the difference between the price before the offer and the offer price. In this spirit, we can similarly interpret one value of the discount of control in module and one (positive) control premium, both equal in size. Based on these considerations, we explore if the factors that have an influence on control premium change their sign in the case of the discounts for control (the negative control premiums). The second tested hypothesis is:

Hypothesis 2: Some determining factors have an opposite sign in the case of discount for control comparatively to those which determine the control premium.

If these two hypotheses are validated, the results have a pivotal implication. In this case, the models used for the general case of control premium are not useful for modelling the discount for control, which has to be approached differently. Practically, it seems reasonable to expect the existence of the turning point where the interest for taking control is transformed into an interest for not having the control.

\section{Methodology and Data}

In order to find the possible determinants of the discount for control, we used linear regression models. We estimated the size of the discount using the relation used in several other papers for estimating the control premium (e.g. Barclay and Holderness, 1989). The size

5 For the particular case of countries in transition to market economy, in the privatization process, shares are sometimes sold at a discount (Fidrmuc, 2007). In these cases, it is also important to take into account the foreign direct investments because they can have a larger impact on a state economy (Gorbunova et al, 2012). 
of the discount for control $(d c)$ (which can be considered an inverse of the control premium ${ }^{6}$, $c p$ ) was calculated as difference between the price before the announcement $\left(P_{t-1}\right)$ and the offer price $\left(P_{O, t}\right)$, divided by the price before the announcement $\left(P_{t-1}\right)$ :

$$
d c=-c p=-\frac{P_{O, t}-P_{t-1}}{P_{t-1}}=\frac{P_{t-1}-P_{O, t}}{P_{t-1}}
$$

Different relations are used for the estimation of the control premium, each of them having certain advantages and disadvantages. For a discussion regarding the applicability of these relations for the case of the Romanian listed companies and for the reasons that justify this preference, see Dragotă et al. (2013). Two key variables appear in relation (1), respectively the offer price and the price before the announcement. The price before the announcement reflects the perspective of the market. However, in some cases, assets are traded rarely, so the last price can reflect different perspectives comparatively to the ones present at the moment of the offer ${ }^{7}$. Moreover, and even more important, is the noncoincidence between assets' prices and their rational, based on fundamentals, intrinsic values, hypothesis formulated before in some previous studies on Romanian capital market efficiency (e.g. Dragotă and Mitrică, 2004). This difference between price and intrinsic values can explain some 'strange' values of the discount for control. In the same context, the offer price reflects the interest of the bidder, and from his or her perspective, it should be as lower as possible; however, the decision to accept the offer made by the seller of the shares is hardly understandable from a rational point of view, especially for the case of discounts of almost $100 \%$. For this reasons, the control premium estimated through relationship (1) should be used cautiously in the practice of business valuation. On the other hand, it is appropriate for explaining the characteristics of the transactions in which the offer price is below the previous price recorded on the market.

In some cases, for one transaction, more than one control premiums are recorded and the difference between the initial premium and the final premium is directly influenced by the probability of competition that can appear (Eckbo, 2009). For our database, only one offer was recorded for each transaction. For this reason, only one control premium was calculated for each operation.

We ran multiple regressions using several variables that can influence the value of the discount for control. These variables are described in Table 2. Most of the analysed determinants were used in other studies, but we tested, as far as we know, some other new variables. As such, we included in our analysis the rates of return of the target-companies (see ROA and COA), in order to test if the profitability of the target-companies have an influence on the size of discount for control. We preferred dummy variables and not percentages of shares detained by different classes of shareholders (as in Ødegaard, 2007), mainly because an increase in the percentage detained by a shareholder does not determine an increase in the effective vote power over a limit (e.g. 50\% is this limit for a simple control; an increase in the percentage of shares detained, e.g. from $60 \%$ to $70 \%$ does not give any supplementary power in decision).

$6 \quad$ Practically, discount for control $=-($ control premium $)$.

7 For this reason, we have considered in regressions some variables for taking into account the lack of liquidity persistent on the market. 


\begin{tabular}{|c|c|c|}
\hline Indicator & Explanation & Other studies \\
\hline CAP & $\begin{array}{l}\text { The total capitalization (million RON) } \\
\text { of the target-company before the transaction - proxy for } \\
\text { the firm size. We have used } \ln (\mathrm{CAP}) \text { in the regression. }\end{array}$ & $\begin{array}{l}\text { Barclay and Holderness } \\
\text { (1989), Nenova (2003), } \\
\varnothing \text { degaard (2007) }\end{array}$ \\
\hline PBA & $\begin{array}{l}\text { Stake owned by the buyer before the announcement day } \\
\text { - proxy for the bargaining power of the buyer. }\end{array}$ & $\begin{array}{l}\text { Walkling and Edmister } \\
\text { (1985), Dyck and Zingales } \\
\text { (2004), Kruse and Suzuki } \\
\text { (2013) }\end{array}$ \\
\hline PSP & Percentage of shares purchased in the transaction. & $\begin{array}{l}\text { Walkling and Edmister } \\
\text { (1985), Barclay and } \\
\text { Holderness (1989), Dyck } \\
\text { and Zingales (2004) }\end{array}$ \\
\hline HHI & $\begin{array}{l}\text { Ownership concentration index (Herfindahl-Hirschman } \\
\text { index) of the target company. } \mathrm{HHI} \text { is determined as } \\
\text { the sum of the squares of percentages of common } \\
\text { shares owned by the important shareholders before } \\
\text { the transaction. We defined an important shareholder if } \\
\text { he or she owns more than } 5 \% \text { of shares. }\end{array}$ & $\begin{array}{l}\text { Duggal and Millar (1999), } \\
\text { Nenova (2003), Gaspar } \\
\text { et al. (2005) }\end{array}$ \\
\hline ATC & $\begin{array}{l}\text { The total annual turnover divided by the total } \\
\text { capitalization before the transaction of the target- } \\
\text { company. }\end{array}$ & Dragotă et al. (2013) \\
\hline AAT & $\begin{array}{l}\text { Average annual turnover of the target listed companies } \\
\text { in the period 2000-2014. We have used } \ln (\text { AAT) in } \\
\text { the regression. }\end{array}$ & $\begin{array}{l}\varnothing \text { degaard (2007), Dragotă } \\
\text { et al. (2013) }\end{array}$ \\
\hline NTD & $\begin{array}{l}\text { The number of non-trading days before the transaction } \\
\text { (for the target company). }\end{array}$ & Dragotă et al. (2013) \\
\hline DPERS & $\begin{array}{l}\text { Buyer's type - dummy variable ( } 1 \text { if the buyer is } \\
\text { a corporation, } 0 \text { if the buyer is an individual). }\end{array}$ & $\begin{array}{l}\text { Barclay and Holderness } \\
\text { (1989), Dragotă et al. (2013) }\end{array}$ \\
\hline DDA & $\begin{array}{l}\text { Dummy variable for the buyer's type ( } 1 \text { if the buyer is } \\
\text { a domestic company, } 0 \text { if the buyer is a foreign company). }\end{array}$ & $\begin{array}{l}\text { Barclay and Holderness } \\
\text { (1989), Kang and Kim } \\
\text { (2008), Ragozzino and } \\
\text { Reuer (2011) }\end{array}$ \\
\hline DDO & $\begin{array}{l}\text { Dummy variable for the type of the major shareholder (of } \\
\text { the target company) before the transaction ( } 1 \text { if the owner } \\
\text { is a domestic corporation, } 0 \text { if is a foreign corporation). }\end{array}$ & Dragotă et al. (2013) \\
\hline DCMS & $\begin{array}{l}\text { Dummy variable for target company with a major } \\
\text { shareholder (more than } 50 \% \text { of shares) ( } 1 \text { if the company } \\
\text { has a major shareholder, } 0 \text { otherwise). }\end{array}$ & $\begin{array}{l}\text { Hanousek et al. (2007), } \\
\text { Bena and Hanousek (2008), } \\
\text { Dragotă et al. (2013) }\end{array}$ \\
\hline DCIS & $\begin{array}{l}\text { Dummy variable for target company with few important } \\
\text { shareholders (target companies with one or more } \\
\text { shareholders having more than } 33 \% \text { but not more than } \\
50 \% \text { of the target's equity) ( } 1 \text { if the company is in this } \\
\text { situation, } 0 \text { otherwise). }\end{array}$ & $\begin{array}{l}\text { Hanousek et al. (2007), } \\
\text { Bena and Hanousek (2008), } \\
\text { Dragotă et al. (2013) }\end{array}$ \\
\hline
\end{tabular}




\begin{tabular}{|l|l|l|}
\hline Indicator & \multicolumn{1}{|c|}{ Explanation } & \multicolumn{1}{|c|}{ Other studies } \\
\hline DCDO & $\begin{array}{l}\text { Dummy variable for target company with a diversified } \\
\text { ownership (no shareholder owns more than 33\%) (1 if } \\
\text { the company is in this situation, 0 otherwise). }\end{array}$ & $\begin{array}{l}\text { Hanousek et al. (2007), } \\
\text { Bena and Hanousek (2008), } \\
\text { Dragotă et al. (2013) }\end{array}$ \\
\hline COA & $\begin{array}{l}\text { The cash ratio recorded in the takeover year for the target } \\
\text { company. We have calculated the cash ratio as the total } \\
\text { value of the cash and cash equivalents divided by the total } \\
\text { assets. }\end{array}$ & \\
\hline ROA & $\begin{array}{l}\text { The return on asset ratio recorded in the takeover year by } \\
\text { the target company. We have calculated ROA as the net } \\
\text { profit divided by the total assets. }\end{array}$ & \\
\hline DLAW & $\begin{array}{l}\text { Dummy variables for the change in capital market } \\
\text { legislation (from July 2004), imposing a minimum bidding } \\
\text { price. DLAW is defined as 1 for the presence of this } \\
\text { legislation (after July 2004), 0 in its absence (before July } \\
\text { 2004). }\end{array}$ & \\
\hline DSEC & $\begin{array}{l}\text { Industry sector - dummy variable } \\
\text { (1 for the target company acting in an industry, 0 in other } \\
\text { industry). We have analysed two industries, respectively } \\
\text { services (DSERV) and processing industries (DPROC). }\end{array}$ & $\begin{array}{l}\text { Dragotă et al. (2013) } \\
\text { Drack and Zingales (2004), }\end{array}$ \\
\hline
\end{tabular}

Source: the authors.

We tested some other variables, which were found statistically insignificant in the regressions (e.g. the stake owned by the buyer before the announcement day - proxy for the bargaining power of the buyer). We also tested another measure for firm size (total assets, AT) (like in Dyck and Zingales, 2004; Maury and Pajuste, 2005; and Albuquerque and Schroth, 2010), but it was strongly (directly) correlated with the total capitalization. We were also interested to analyse the potential impact of the return on equity (ROE) on the size of the discount for control. However, the book value of the shareholders' equity was in many cases negative, making ROE irrelevant from a financial point of view.

The indicators were obtained using data provided by Bucharest Stock Exchange. The correlation matrix between the variables is presented in Appendix 1. We tested for linearity using Ramsey RESET Test (Ramsey, 1969).

We included in our database only those tender offers recorded on the Romanian capital markets (Bucharest Stock Exchange and RASDAQ, the Romanian over the counter market) that had the tender offer bid price $\left(\mathrm{P}_{0, t}\right)$ below the share price before the starting date of the tender offer $\left(\mathrm{P}_{\mathrm{t}-1}\right)$. Even if the capital market regulations in Romania impose a minimum bidding price ${ }^{8}$, a tender offer price far lower than the last share price is possible. The actual regulation $^{9}$ states that the bidding price should be higher than the price already paid by

8 This restriction is stipulated by the Law 297/2004 on the capital markets and by other regulations issued by the National Securities Commission of Romania (NSCR).

9 Regulation No.1/2006 issued by the National Securities Commission of Romania (NSCR) regarding the issuers and the public offer operations. 
the acquirer during the last 12 months and, if this is not the case, the price should be higher than the average weighted market prices recorded in the same period. Our database includes mainly transaction performed before 2004, when these regulations did not occurred, and this is an explanation why we recorded discount for control premium of $80-90 \%$. Also, for those transactions performed after 2004, the limits imposed for the bidding price by regulations, were taken into consideration. For taking into account the impact of this change in legislation, we considered a dummy variable (DLAW) (see Table 2).

Table 3 | Descriptive Statistics for the Discount for Control (in \%)

\begin{tabular}{|c|c|c|c|c|c|c|}
\hline Indicator & $\begin{array}{c}\text { Number of } \\
\text { Observations }\end{array}$ & Mean & $\begin{array}{c}\text { Standard } \\
\text { Deviation }\end{array}$ & Median & Min. & Max. \\
\hline Value & 46 & 44.44 & 29.34 & 40.27 & 0.11 & 98.28 \\
\hline
\end{tabular}

Source: own calculation, based on data provided by Bucharest Stock Exchange.

Figure 1 | Distribution of the Discount for Control (in \%) for the Discounted Tender Offer Bids Made between 2000 and 2014

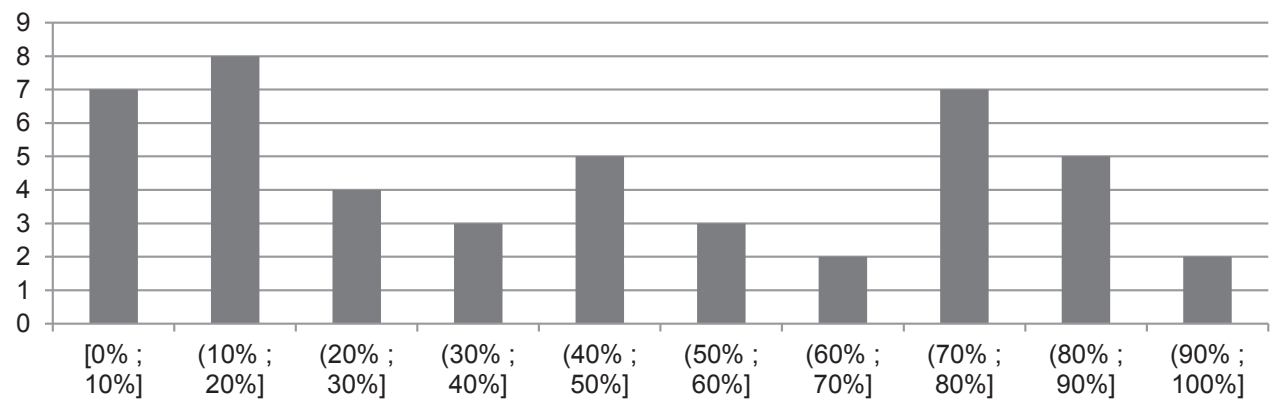

The distribution of the discount for control

Source: own calculation, based on data provided by Bucharest Stock Exchange.

We took into account the transactions that determined a change in controlling position, but also those in which only an intention to take the control, but finished without the gain of control, occurred. We founded 46 discounted tender offers between 2000 and 2014. In 28 cases the transaction was finished successfully. We tested if the success of the offer has determined a specific behaviour for the discount for control, but the results have proved that the two populations have similar features.

The number of cases included in our database is obviously small. However, the statistical population of such cases is complete for the Romanian capital market in the analysed period. Finally, this small number of cases explains why the discount offers for taking the control is not usual on capital market.

Table 3 provides some descriptive statistics for the discount for control. The distribution of the negative control premiums is presented in Figure 1. The discount has an average of $44 \%$ and a median of $40 \%$. The lowest discount for control is nearly $0(0.11 \%)$ and the highest is $98.28 \%$ (some tender offers ended with a change in control with a discount 
for control higher than $90 \%$, meaning that shareholders sold their equity shares for almost nothing).

Some descriptive statistics for the variables used in the regression are presented in Table 4.

Table 4 | Summary Statistics for the Determinants of the Discount for Control

\begin{tabular}{|l|l|r|r|r|r|r|}
\hline Variables & $\begin{array}{c}\text { Units of } \\
\text { Measurement }\end{array}$ & \multicolumn{1}{c|}{ Mean } & \multicolumn{1}{c|}{ Median } & \multicolumn{1}{c|}{$\begin{array}{c}\text { Standard } \\
\text { Deviation }\end{array}$} & \multicolumn{1}{c|}{ Min. } & Max. \\
\hline CAP & RON & $6,417,250.58$ & $1,015,002.94$ & $18,379,636.77$ & 84613.20 & $92,765,655.45$ \\
\hline PBA & Percent & 17.59 & 7.60 & 19.77 & 0.00 & 49.87 \\
\hline PSP & Percent & 32.04 & 32.48 & 27.20 & 0.00 & 95.84 \\
\hline HHI & Numeric & 0.28 & 0.26 & 0.17 & 0.02 & 0.64 \\
\hline ATC & Numeric & 0.27 & 0.19 & 0.26 & 0.00 & 1.25 \\
\hline AAT & RON & $843,421.82$ & $157,338.78$ & $2,993,400.22$ & 492.45 & $19,673,588.17$ \\
\hline NTD & Days & 73.87 & 8.00 & 168.46 & 0.00 & $1,018.00$ \\
\hline DPERS & Dummy & 0.85 & 1.00 & 0.36 & 0.00 & 1.00 \\
\hline DDA & Dummy & 0.74 & 1.00 & 0.44 & 0.00 & 1.00 \\
\hline DDO & Dummy & 0.85 & 1.00 & 0.36 & 0.00 & 1.00 \\
\hline DCMS & Dummy & 0.37 & 0.00 & 0.49 & 0.00 & 1.00 \\
\hline DCIS & Dummy & 0.33 & 0.00 & 0.47 & 0.00 & 1.00 \\
\hline DCDO & Dummy & 0.30 & 0.00 & 0.47 & 0.00 & 1.00 \\
\hline COA & Percent & 6.87 & 2.61 & 12.93 & 0.01 & 75.29 \\
\hline ROA & Percent & -15.61 & 0.79 & 58.24 & -316.51 & 48.51 \\
\hline DLAW & Dummy & 0.29 & 0.00 & 0.46 & 0.00 & 1.00 \\
\hline DPROC & Dummy & 0.65 & 1.00 & 0.48 & 0.00 & 1.00 \\
\hline DSERV & Dummy & 0.35 & 0.00 & 0.48 & 0.00 & 1.00 \\
\hline
\end{tabular}

Note: The definitions of the variables from this table are provided in Table 2.

Source: Own calculation.

\section{Results}

For examining the potential determinants of the discount for control, we ran several regressions. We did not consider in the same regression the variables correlated at a higher level than 0.3 in module. The seven most relevant regressions are included in Table 5. 
Table 5 | The Determinants of the Discounts for Control Regressions

\begin{tabular}{|c|c|c|c|c|c|c|c|}
\hline & (1) & (2) & (3) & (4) & (5) & (6) & (7) \\
\hline \multicolumn{8}{|l|}{ Variable } \\
\hline $\ln (C A P)$ & $\begin{array}{l}0.04^{* *} \\
(1.49)\end{array}$ & & $\begin{array}{l}0.04^{* *} \\
(2.21)\end{array}$ & $\begin{array}{l}0.006 \\
(0.34)\end{array}$ & $\begin{array}{c}0.02 \\
(1.35)\end{array}$ & $\begin{array}{c}0.01 \\
(0.98)\end{array}$ & \\
\hline PBA & $\begin{array}{c}-0.02 \\
(-0.09)\end{array}$ & $\begin{array}{l}-0.27 \\
(-1.07)\end{array}$ & & & & & \\
\hline PSP $^{2}$ & $\begin{array}{l}0.51 * * * \\
(3.81)\end{array}$ & & $\begin{array}{l}0.57^{* * *} \\
(2.99)\end{array}$ & & & $\begin{array}{l}0.44 * * * \\
(3.11)\end{array}$ & \\
\hline HHI & $\begin{array}{c}0.39 \\
(1.47) \\
\end{array}$ & $\begin{array}{c}0.34 \\
(1.31) \\
\end{array}$ & & & & $\begin{array}{l}0.53^{* *} \\
(2.23)\end{array}$ & $\begin{array}{c}0.34 \\
(1.23) \\
\end{array}$ \\
\hline ATC & & $\begin{array}{l}-0.43 * * \\
(-2.11) \\
\end{array}$ & & $\begin{array}{l}-0.37 * * \\
(-2.06) \\
\end{array}$ & & & $\begin{array}{l}-0.37^{* *} \\
(-2.52)\end{array}$ \\
\hline $\ln (\mathbf{A A T})$ & & $\begin{array}{l}0.003 \\
(0.23) \\
\end{array}$ & & & & & \\
\hline NTD & $\begin{array}{l}0.0008^{* * *} \\
(4.27)\end{array}$ & & $\begin{array}{l}0.01 * * * \\
(6.05)\end{array}$ & & $\begin{array}{l}0.001 * * * \\
(3.98)\end{array}$ & & \\
\hline DPERS & $\begin{array}{l}-0.21 * * \\
(-2.02)\end{array}$ & $\begin{array}{l}-0.08 \\
(-0.61)\end{array}$ & $\begin{array}{l}-0.16 * \\
(-1.91)\end{array}$ & $\begin{array}{l}-0.07 \\
(-0.53)\end{array}$ & $\begin{array}{l}-0.22^{* *} \\
(-2.25)\end{array}$ & $\begin{array}{l}-0.15 \\
(-1.32)\end{array}$ & $\begin{array}{l}-0.05 \\
(-0.55)\end{array}$ \\
\hline DDA & & & & & $\begin{array}{l}-0.004 \\
(-0.04) \\
\end{array}$ & & $\begin{array}{r}0.12 * \\
(1.75) \\
\end{array}$ \\
\hline DDO & & & $\begin{array}{l}0.05 \\
(0.42) \\
\end{array}$ & $\begin{array}{c}0.08 \\
(0.63) \\
\end{array}$ & & $\begin{array}{c}0.17^{*} \\
(1.71) \\
\end{array}$ & \\
\hline DCMS & & & & $\begin{array}{l}0.19 * * \\
(2.08) \\
\end{array}$ & & & \\
\hline DCIS & & & & & $\begin{array}{l}-0.21 * * \\
(-2.25)\end{array}$ & & \\
\hline DCDO & & & $\begin{array}{l}-0.03 \\
(-0.51) \\
\end{array}$ & & & & \\
\hline COA & $\begin{array}{l}-0.41 * \\
(-1.97) \\
\end{array}$ & $\begin{array}{l}-0.26 \\
(-1.11)\end{array}$ & $\begin{array}{l}-0.44^{* *} \\
(-2.19)\end{array}$ & $\begin{array}{l}-0.25 \\
(-1.06) \\
\end{array}$ & $\begin{array}{l}-0.31 \\
(-1.52) \\
\end{array}$ & & $\begin{array}{l}-0.008 \\
(-0.15) \\
\end{array}$ \\
\hline ROA & & $\begin{array}{c}0.01 \\
(0.17)\end{array}$ & $\begin{array}{l}0.08 * * \\
(2.08)\end{array}$ & $\begin{array}{l}0.03 \\
(0.52)\end{array}$ & & & $\begin{array}{l}-0.25 \\
(-1.17)\end{array}$ \\
\hline DLAW & & & & & & & $\begin{array}{l}-0.21^{* *} \\
(-2.06) \\
\end{array}$ \\
\hline DPROC & & $\begin{array}{l}-0.08 \\
(-0.89) \\
\end{array}$ & $\begin{array}{l}-0.07 \\
(-0.68) \\
\end{array}$ & & $\begin{array}{l}-0.04 \\
(-0.39) \\
\end{array}$ & & \\
\hline DSERV & $\begin{array}{c}0.08 \\
(0.81) \\
\end{array}$ & & & $\begin{array}{c}0.07 \\
(0.68) \\
\end{array}$ & & & \\
\hline Intercept & $\begin{array}{l}-0.16 \\
(-0.55)\end{array}$ & $\begin{array}{l}0.54^{* *} \\
(2.68)\end{array}$ & $\begin{array}{l}-0.11 \\
(-0.36) \\
\end{array}$ & $\begin{array}{r}0.38 \\
(1.15) \\
\end{array}$ & $\begin{array}{c}0.31 \\
(1.27) \\
\end{array}$ & $\begin{array}{l}-0.14 \\
(-0.43) \\
\end{array}$ & $\begin{array}{l}0.48^{* * * *} \\
(4.26)\end{array}$ \\
\hline R-squared (in \%) & 41.84 & 24.95 & 40.76 & 26.54 & 36.44 & 21.71 & 29.62 \\
\hline $\begin{array}{l}\text { Adjusted R-squared } \\
\text { (in \%) }\end{array}$ & 29.27 & 8.93 & 25.95 & 10.55 & 24.41 & 11.91 & 16.66 \\
\hline \multicolumn{8}{|l|}{ RESET Test } \\
\hline t-statistics & -0.83 & 1.04 & 0.32 & 0.43 & -1.42 & -0.11 & 1.21 \\
\hline Probability & 0.41 & 0.28 & 0.74 & 0.66 & 0.19 & 0.91 & 0.23 \\
\hline
\end{tabular}

Note: This table reports the specific determinants of the discount for control of a company in 7 regressions. The definitions of the variables from this table are provided in Table 2. t-statistics are in parentheses. We also included the Ramsey Regression Equation Specification Error Test (RESET) test statistics (FITTED^2). The symbols ${ }^{* * *},{ }^{* * *}$ denotes statistical significance at the 10,5 , and $1 \%$ levels, respectively.

Source: Own calculation, based on data provided by Bucharest Stock Exchange. 
We also tested the impact of other variables (e.g. the solvency ratio; GDP/capita in the year of transaction; dummies for the years; dummies for negative net earnings in the last years, but also in the last two years before the transaction; dummy for delisting the company in less than two years after the transaction; dummy for the active investor (if the acquirer already owns shares of the target-company or not) but they were insignificant in all the regressions.

Ramsey RESET Test (Ramsey, 1969) revealed nonlinear functional forms. We identified that the variable PSP is responsible for the nonlinear test results and we considered squared value for PSP in the regressions. Using the database of Dragotă et al. (2013), we performed similar regressions and obtained an increase of Adjusted $\mathrm{R}^{2}$ when $\mathrm{PSP}^{2}$ is used in regressions instead of PSP.

The determinants of the discount for control were compared to those of the control premium, according to Dragotă et al. (2013) (see Table 6). Dragotă et al. (2013) included in their study positive and negative control premiums, but with prevalence for the positive cases (in their database were included 173 cases, with 18 negative control premiums and 155 positive ones). For comparison, in Table 6, we preferred the term 'control premium' both for the positive and for the negative control premiums. Thus, a negative control premium will be equal to (the discount for control).

As we mentioned before, control premium and discount for control can be interpreted in two different ways. On the one hand, a discount for control can be understood as a negative control premium. For instance, algebraically, $\frac{\partial c p}{\partial A T C}>0$ is analogous, based on the definition of the discount for control, with $\frac{\partial d c}{\partial A T C}<0$. In this spirit, a reverse in the results presented in columns (3) and (4) from Table 6 can signify a switch in the behaviour of the control premium when the dependent variable becomes negative. For instance, we find that $\frac{\partial c p}{\partial P S P}>0$ for the general case, but $\frac{\partial c p}{\partial P S P}<0$ if we consider only negative values of control premium. On the other hand, a discount for control can be understood as a magnitude of the difference between the price before the offer and the offer price. In this spirit, we can similarly interpret one value of the discount of control in module and one (positive) control premium, both equals in size.

The discount for control is related to the size of the company (measured through the market capitalization). The result is similar to Dragotă et al. (2013). However, the economic significance is substantially different: for the discount offers, the larger the company is, the higher the discount will be. In other words, the difference between the price before the offer and the offer price is increasing with the size of the company. The hypothesis of the cost of non-diversification of the portfolio proposed by Barclay and Holderness (1989) is confirmed. This result is different from those recorded by Nenova (2003) and Gaspar et al. (2005). 
Table 6 | Explanatory Variables Used in the Models. The Dependent Variable Is the Control Premium (even it is negative).

We have compared the results of this study with Dragotă et al. (2013). In parentheses there is the correlation sign between the discount for control and the independent variable.

\begin{tabular}{|c|c|c|c|}
\hline Indicator & Notation & $\begin{array}{l}\text { Significant in } \\
\text { Dragotă et al. (2013) }\end{array}$ & $\begin{array}{l}\text { Significant in } \\
\text { this study }\end{array}$ \\
\hline (1) & (2) & (3) & (4) \\
\hline The total capitalization & CAP & $\begin{array}{c}\text { YES } \\
(-)\end{array}$ & $\begin{array}{c}\text { YES } \\
(-)\end{array}$ \\
\hline $\begin{array}{l}\text { Stake owned by the buyer before } \\
\text { the announcement day }\end{array}$ & PBA & $\begin{array}{c}\text { YES } \\
(-)\end{array}$ & NO \\
\hline $\begin{array}{l}\text { Percentage of shares purchased } \\
\text { in the transaction }\end{array}$ & PSP & $\begin{array}{c}\text { YES } \\
(+)\end{array}$ & $\begin{array}{c}\text { YES } \\
(-)\end{array}$ \\
\hline Ownership concentration index & $\mathrm{HHI}$ & $\begin{array}{c}\text { YES } \\
(+)\end{array}$ & $\begin{array}{c}\text { YES } \\
(-)\end{array}$ \\
\hline $\begin{array}{l}\text { The total annual turnover } \\
\text { divided by the total } \\
\text { capitalization }\end{array}$ & ATC & $\begin{array}{c}\text { YES } \\
(+)\end{array}$ & $\begin{array}{c}\text { YES } \\
(+)\end{array}$ \\
\hline $\begin{array}{l}\text { Average annual turnover } \\
\text { of the target-company }\end{array}$ & AAT & $\begin{array}{c}\text { YES } \\
(+)\end{array}$ & NO \\
\hline Number of not trading days & NTD & NO & $\begin{array}{l}\text { YES } \\
(-)\end{array}$ \\
\hline $\begin{array}{l}\text { The buyer's type - corporation } \\
\text { or individual }\end{array}$ & DPERS & $\begin{array}{c}\text { YES } \\
(+)\end{array}$ & $\begin{array}{c}\text { YES } \\
(+)\end{array}$ \\
\hline $\begin{array}{l}\text { The buyer's type (the owner is } \\
\text { a domestic / foreign corporation) }\end{array}$ & DDA & $\begin{array}{c}\text { YES } \\
(+)\end{array}$ & $\begin{array}{l}\text { YES } \\
(-)\end{array}$ \\
\hline $\begin{array}{l}\text { The major shareholder's type } \\
\text { (of the target company) before } \\
\text { the transaction (the owner is } \\
\text { a domestic / foreign corporation) }\end{array}$ & DDO & $\begin{array}{l}\text { YES } \\
(+)\end{array}$ & $\begin{array}{l}\text { YES } \\
(-)\end{array}$ \\
\hline $\begin{array}{l}\text { The major shareholder owning } \\
\text { more than } 50 \% \text { of shares }\end{array}$ & DCMS & $\begin{array}{l}\text { YES } \\
(+)\end{array}$ & $\begin{array}{l}\text { YES } \\
(-)\end{array}$ \\
\hline $\begin{array}{l}\text { The major shareholder owning } \\
\text { more than } 33 \% \text { but not more } \\
\text { than } 50 \%\end{array}$ & DCIS & $\begin{array}{l}\text { YES } \\
(+)\end{array}$ & $\begin{array}{l}\text { YES } \\
(+)\end{array}$ \\
\hline $\begin{array}{l}\text { No one of the shareholders } \\
\text { owning more than } 33 \%\end{array}$ & $\mathrm{DCDO}$ & $\begin{array}{l}\text { YES } \\
(-)\end{array}$ & NO \\
\hline Industry sector & DSEC & $\begin{array}{c}\text { YES (but not for all*) } \\
\text { (different signs depending on } \\
\text { the industry) }\end{array}$ & NO \\
\hline
\end{tabular}

Note: * In Dragotă et al. (2013) 8 industry dummies were used, respectively for companies acting in: (1) agriculture; (2) clothing industry; (3) construction; (4) food industry; (5) chemistry industry; (6) machinery and equipment industry; (7) manufactory; (8) service industry. In this study we split into only two sectors (INDUSTRIES and SERVICES) due to the smaller sample.

Source: Own research. 
The percentage of shares purchased in the transaction (PSP) has a positive impact on the size of the discount for control. A higher percentage of shares bought by the acquirer can lead to a higher discount, result concordant with the practice of negotiation, and not with the agency problems hypothesis, as in Dragotă et al. (2013). If the acquirer is willing to buy the controlling block of shares for a company with financial problems, he or she will convince easier the target's owners to sell their share at a high discount. This result is not in accordance with the studies of Barclay and Holderness (1989) and Dyck and Zingales (2004), which state that target shareholders should demand more in the case of a large and known company on the market. It was interesting to find out that $\mathrm{PSP}^{2}$ explains better the discount for control (an increase in adjusted $\mathrm{R}^{2}$ was found).

The ownership concentration index (HHI) is directly related to the discount for control. Dragotă et al. (2013) found out that an increase in HHI determines an increase in the level of control premiums. This direct relation between the ownership concentration and the premium is also present in other studies like Nenova (2003) or Gaspar et al. (2005). Taking into account only the negative control premiums, the dependence is inversed. A higher concentration in the ownership of the target-company (a higher level of HHI) is associated with a higher discount, in other words, a higher difference between the price before the transaction and the offer price. It is possible that this higher discount to be the result of a private negotiation between parties. On the other hand, even if the companies are in financial distress, especially companies with a large number of shareholders, not all of them will be disposed to sell their shares with a high discount, waiting for a better price. If the company has one major shareholder, he or she is more likely to accept an offer below the market value for his or her shares if the company is in financial distress (the same explanation for DCMS, too).

The difference between the offer price and the last price on the market can be determined also by the lack of liquidity (Ødegaard, 2007). As such, we included in our analysis some variables for liquidity. The annual turnover divided by the market capitalization (ATC) (proxy for the liquidity) determines a decrease of the discount. Also, a lack of liquidity (measured through the number of days that have passed between the last day of trading and the beginning of the tender offer, NTD) has a positive effect on the value of the discount for control ${ }^{10}$. The result is expected as long as, in general, the less liquid assets are traded at a discount, and the lower the liquidity is, the larger this discount for illiquidity is. Many companies from emerging market countries may face this problem. For example, Romania between 2000 and 2010 faced political crisis or rapid change in fiscal regulation that made the investment in this economic environment risky. This issue leaded to fewer transactions, and so to a low level of liquidity on the capital market.

In Dragotă et al. (2013), being a domestic owner (DDO) or acquirer (DDA) had a positive influence on the control premium, like in Barclay and Holderness (1989), Ragozzino and Reuer (2011) or Albuquerque and Schroth (2010). In our case, the presence of the domestic investors increases the level of the discount for control. In the case of the domestic acquirer, this can be interpreted as a higher ability or power in negotiation, but the situation is reversed in the case of the domestic seller, which seems to accept a higher discount. The correlation between the distance and the asymmetric information between

10 Not all the proxies for liquidity or for the lack of liquidity were statistically significant, e.g. the average annual turnover of the target-company (AAT) and the number of trading days (in the period 2000-2014) for the target-company. 
the acquirer and the target can be another explanation (Ragozzino and Reuer, 2011). We expect that nearby acquirers are in better position to appreciate the key resources of the target company (e.g. human capital, key technologies, brands, growth prospects, and relationships with other companies and customers), while distant acquirers are likely to lack this kind of information and rely only on accounting data. This fact can drive domestic investors to higher discount premiums.

Barclay and Holderness (1989) confirm that the type of the investor has an influence on the size of the control premium. In our study, if the acquirer is a corporation (DPERS), the discount is lower. This can be interpreted as a higher interest of the corporations to take the control over the target-company, and to pay a higher price, which can be supporting for the potential synergistic effects, but also for the persistent agency problems (Dragotă et al., 2013). Moreover, individuals are usually looking for opportunities on the market. They will prefer shares (at a low price) that can produce high benefits in the future.

The presence of the second important shareholder (DCIS) determines a decrease of the discount. The result confirms his or her role in monitoring explained by Maury and Pajuste (2005). The second important shareholder is interested in protecting his or her wealth, and does not accept easily a relatively low price.

Financial performance has an influence on the value of the discount. Surprisingly, the return on assets (ROA) has a positive influence on the discount for control. The limited database makes us circumspect in formulating an explanation. An increase in terms of cash and cash equivalents (COA) will determine a decrease of the discount for control according to expectations.

As expected, the regulations regarding a minimum price for offers determined a decrease in discount for control. The result can be interpreted as a success for the regulators, for protecting the small shareholders' interests.

We tested if the successful transaction (in which the control was taken) determined a specific behaviour comparatively to the cases in which the offer was unsuccessful. This variable was not statistically significant. Privatization process can be an explanation for selling the companies with discount (Fidrmuc, 2007). We analysed both the case of state owned companies and those where the state owns a percentage of the company equity, but this factor is not a determinant variable for the discount for control (we tested as variables a dummy for the state presence in the company ownership and, also, the percentage owned by the state in each target company).

Some variables that were found significant for the general case in Dragotă et al. (2013) were not significantly taking into account only the negative control premiums, respectively the average annual turnover, the number of trading days for the target-company, the dummy for the active investor, the stake owned by the buyer before the announcement day, the dummy variable for target company with a diversified ownership. Also, the sector has no influence on the level of the discount for control ${ }^{11}$.

\section{Conclusions}

The discount for control can raise many questions. Even accepting a discount for selling the large package of shares is sometimes hard to understand from a rational perspective. In

11 Authors used two dummy variables for analysing the sector, respectively for industrial companies (DIND) and in services (DSERV). 
this paper we investigated the discounts for control for the tender offer bids recorded on the Romanian capital market between 2000 and 2014. In this period, 45 discounted tender offers were launched.

Comparatively to the case of control premiums, we found that the discount for control has some specific determinant factors. In this category, we can include: the number of not trading days and the cash liquidity ratio. Some factors which are relevant in explaining the control premium are not relevant in explaining the discount for control: the average annual turnover, the number of trading days (in the period 2000-2014) for the target-company, the dummy for the active investor, the stake owned by the buyer before the announcement day, the dummy variable for target company with a diversified ownership (no shareholder owns more than $33 \%$ ). Also, the sector has no influence on the level of the discount for control. As result, the factors which are usually considered in explaining the control premium cannot be used for the case of discount for control.

In the regressions run only for explaining the discount for control, some determinants of the general case of control premium (including here both positive and negative control premiums, Dragotă et al., 2013) change their sign. In this category, we can include: the percentage of shares purchased in the transaction, the ownership concentration index, the dummies for the domestic versus foreign buyer, respectively seller, and the dummy for the case if the major shareholder owns over $50 \%$ of shares. This change of sign can be interpreted as a change in the influence on the control premium when it becomes negative, but also as a similar impact on the magnitude of the difference between the price before the offer and the offer price.

From a methodological point of view, at least for Romanian listed companies' case, the square of the percentage of shares purchased in the transaction $\left(\mathrm{PSP}^{2}\right)$ better explains both control premium and the discount for taking the control than PSP. It could be interesting to test this aspect for other markets, too.

It can be possible that the discount for control has a different behaviour. However, it can be possible also that this resulted from the relatively low number of observations. For this reason, it can be interesting to find out if the results are validated for other countries. 


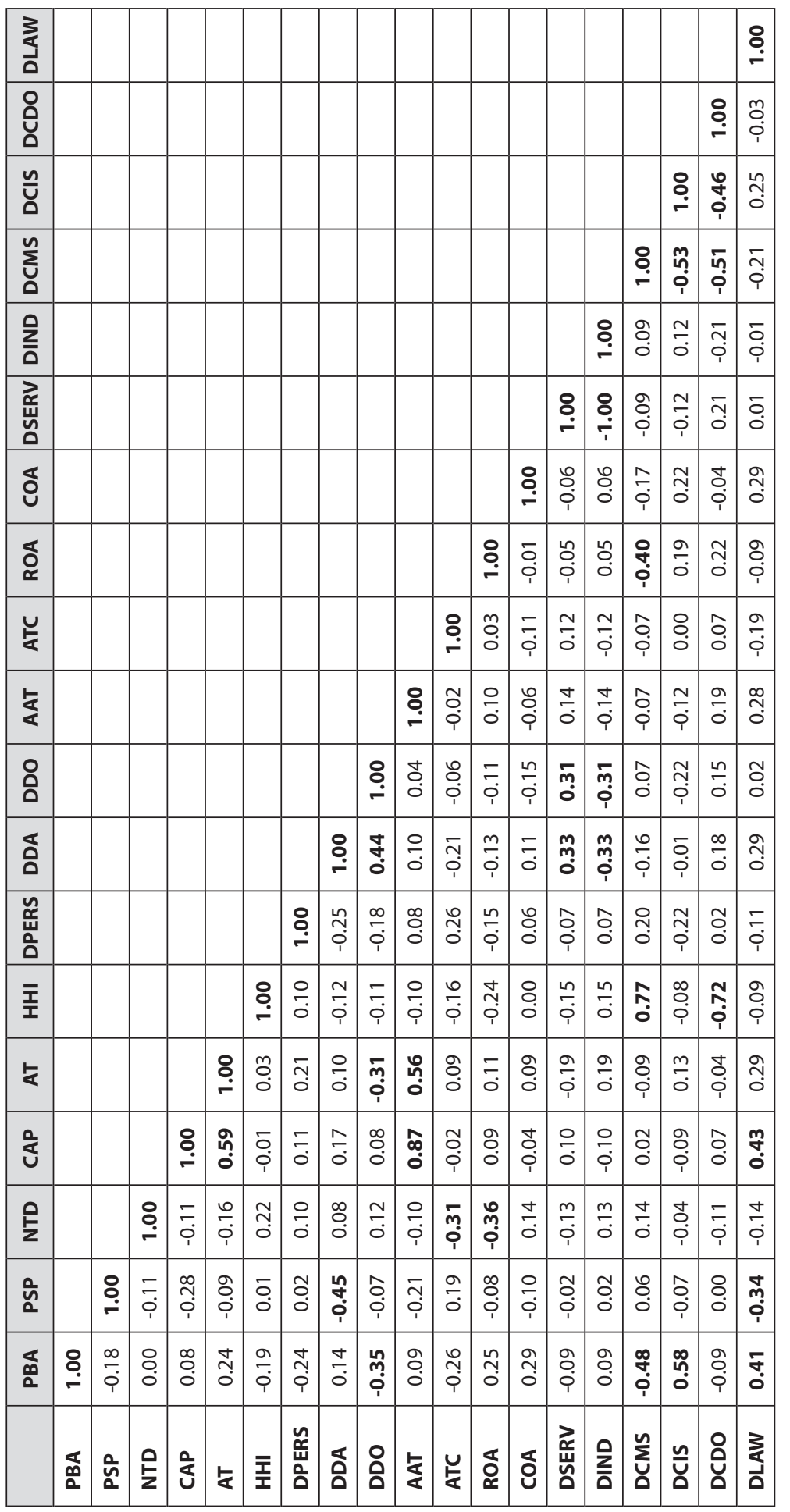

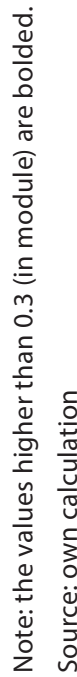




\section{References}

Albuquerque, R., Schroth, E. (2010). Quantifying Private Benefits of Control from a Structural Model of Block Trades. Journal of Financial Economics, 96(1), 33-55. DOI: 10.1016/j.jineco.2009.12.003.

Andrade, G., Mitchell, M., Stafford, E. (2001). New Evidence and Perspectives on Mergers. Journal of Economic Perspectives, 15(2), 103-120. DOI: 10.1257/jep.15.2.103.

Barclay, M. J., Holderness, C. G. (1989). Private Benefits from Control of Public Corporations. Journal of Financial Economics, 25(2), 371-395. DOI: 10.1016/0304-405x(89)90088-3.

Bena, J., Hanousek, J. (2008). Rent Extraction by Large Shareholders: Evidence Using Dividend Policy in the Czech Republic. Finance a úverr - Czech Journal of Economics and Finance, 58, 106-130.

De Paula, G. M., Ferraz, J. C., lootty, M. (2002). Economic Liberalization and Changes in Corporate Control in Latin America. Developing Economies, 40(4), 467-496. DOI: 10.1111/j.1746-1049.2002. tb00923.x.

Dragotă, V., Lipară, C., Ciobanu, R. (2013). Agency Problems and Synergistic Effects in Romania: the Determinants of the Control Premium. Finance a úverr-Czech Journal of Economics and Finance, 63(2), 197-219.

Dragotă, V., Mitrică, E. (2004). Emergent Capital Markets' Efficiency: The Case of Romania. European Journal of Operational Research, 155(2), 353-360. DOI: 10.1016/s0377-2217(03)00093-6.

Duggal, R., Millar, J. A. (1999). Institutional Ownership and Firm Performance: The Case of Bidder Returns. Journal of Corporate Finance, 5(2), 103-117. DOI: 10.1016/s0929-1199(98)00018-2.

Dyck, A., Zingales, L. (2004). Private Benefits of Control: An International Comparison. Journal of Finance, 59(2), 537-600. DOI: 10.1111/j.1540-6261.2004.00642.x.

Eckbo, B. E. (2009). Bidding Strategies and Takeover Premiums: A Review. Journal of Corporate Finance, 15(1), 149-178. DOI: 10.1016/j.jcorpfin.2008.09.016.

Fidrmuc, J. (2007). Channels of Restructuring in Privatized Czech Companies. Economics of Transition, 15(2), 309-339. DOI: 10.1111/j.1468-0351.2007.00287.x.

Gaspar, J. M., Massa, M., Matos, P. (2005). Shareholder Investment Horizons and the Market for Corporate Control. Journal of Financial Economics, 76(1), 135-165.

DOI: $10.1016 /$ j.jfineco.2004.10.002.

Gorbunova, Y., Infante, D., Smirnova, J. (2012). New Evidence on FDI Determinants: An Appraisal over the Transition Period. Prague Economic Papers, 21(2), 129-149. DOI: 10.18267/j.pep.415.

Hanousek, J., Kocenda, E., Svejnar, J. (2007). Origin and Concentration Corporate Ownership, Control and Performance in Firms after Privatization. Economics of Transition, 15, 1-31.

Holderness, C. (2003). A Survey of Blockholders and Corporate Control. Economic Policy Review, 9, 51-64.

Kang, J., Kim, J. (2008). The Geography of Block Acquisitions. Journal of Finance, 63(6), 2817-2858. DOI: $10.1111 / \mathrm{j} .1540-6261.2008 .01414 . x$.

Kruse, T. A., Suzuki, K. (2013). The Impact of Changes in Japanese Tender Offer Regulations on Bidder Behaviour and Shareholder Gains. Working Paper.

Lefort, F., Walker, E. (2007). Do Markets Penalize Agency Conflicts between Controlling and Minority Shareholders? Evidence from Chile. Developing Economies, 45(3), 283-314.

DOI: 10.1111/j.1746-1049.2007.00044.x.

Maury, B., Pajuste, A. (2005). Multiple Large Shareholders and Firm Value. Journal of Banking and Finance, 29(7), 1813-1834. DOI: 10.1016/j.jbankfin.2004.07.002.

Nenova, T. (2003). The Value of Corporate Voting Rights and Control: A Cross - Country Analysis. Journal of Financial Economics, 68(3), 325-351. DOI: 10.1016/s0304-405x(03)00069-2.

$\varnothing$ degaard, B. A. (2007). Price Differences between Equity Classes Corporate Control, Foreign Ownership or Liquidity? Journal of Banking and Finance, 31(12), 3621-3645.

DOI: 10.1016/j.jbankfin.2007.01.013. 
Pop, D. (2006). M\&A Market in Transition Economies: Evidence from Romania. Emerging Markets Review, 7(3), 244-260. DOI: 10.1016/j.ememar.2006.01.003.

Ragozzino, R., Reuer, J. (2011). Geographic Distance and Corporate Acquisitions: Signals from IPO Firms. Strategic Management Journal, 32(8), 876-894. DOI: 10.1002/smj.914.

Ramsey, J. B. (1969). Tests for Specification Errors in Classical Linear Least-Squares Regression Analysis. Journal of the Royal Statistical Society Series B (Methodological), 31(2), 350-371.

Ross, S., Westerfield, R., Jaffe, J. (2010). Corporate Finance. 9th Ed. McGraw Hill.

Shleifer, A., Vishny, R (1986). Large Shareholders and Corporate Control. Journal of Political Economy, 94(3), 461-488. DOI: 10.1086/261385.

Shleifer, A., Vishny, R. (1997). A Survey of Corporate Governance. Journal of Finance, 52(2), 737-783. DOI: $10.2307 / 2329497$.

Walkling, R. A., Edmister, R. O. (1985). Determinants of Tender Offer Premiums. Financial Analysis Journal, 41(1), 27-37. DOI: 10.2469/faj.v41.n1.27. 